\title{
Hesio Cordeiro no I Simpósio sobre Política Nacional de Saúde da Câmara de Deputados, 1979
}

| ${ }^{1}$ Paulo Henrique de Almeida Rodrigues |

${ }^{1}$ Instituto de Medicina Social Hesio Cordeiro, Universidade do Estado do Rio de Janeiro. Rio de Janeiro-RJ, Brasil (pharodrigues@gmail.com). ORCID: 0000-0002-3159-6711

O I Simpósio sobre Política Nacional de Saúde, realizado nos dias 9, 10 e 11 de outubro de 1979, pela Comissão de Saúde da Câmara dos Deputados, foi um dos mais importantes momentos da luta pela Reforma Sanitária, que levou ao reconhecimento do direito universal à saúde e à criação do SUS. Com mais de mais de 900 inscritos, foi um importante palco de disputa entre os interesses do setor privado e os defensores da mudança nas políticas nacionais de saúde. O I Simpósio representou bem o espírito do ano de 1979, em que a crise da ditadura militar resultara na ambígua anistia política decretada pelo general presidente Figueiredo em junho, que perdoou tanto os opositores do regime, quanto os militares e policiais que se envolveram na prisão, tortura e assassinato daqueles opositores. Ainda em 1979, e dois meses depois do I Simpósio, foi aprovada a nova Lei Orgânica dos Partidos Políticos, que extinguiu a ARENA e o MDB, e permitiu a formação de novos partidos políticos, tendo sido criados imediatamente o PMDB, o PDT, o PDS, o PTB e PT - todos com a exceção do PDS se originaram do PMDB.

Refletindo a polarização política da época, o I Simpósio foi presidido pelo deputado do PMDB, partido de oposição ao regime militar, José de Castro Coimbra (1930-...), também presidente da Comissão de Saúde da Câmara, e teve 
como coordenador-geral o Deputado Ubaldo Dantas (1937-), da ARENA, partido da situação, ambos médicos. Entre outros políticos de destaque, estava presente o então deputado da ARENA, Roberto Santos, que mais tarde migrou para o Partido Popular (PP) criado por Tancredo Neves, após a aprovação da nova Lei Orgânica dos Partidos Políticos (Lei no. 6.767/1979 - que extinguiu a ARENA e o MDB e permitiu a formação de novos partidos políticos). Pelo PP, foi ministro da Saúde no governo José Sarney, quando o SUS foi criado. Outra presença importante que mostra bem o espírito da transição política foi Sérgio Arouca, então do Partido Comunista Brasileiro (PCB) falou na Seção de temas livres, no último dia do I Simpósio, sobre "democratização e saúde", em nome do Centro de Estudos Brasileiros em Saúde (CEBES). Sua palestra defendeu as ideias alinhadas por Hesio, José Luís Fiori e Reinaldo Guimarães no célebre documento "A Questão Democrática e a Saúde", que foi abraçado pelo CEBES, como um programa de luta pela reforma sanitária. Vale assinalar, ainda, outra presença do campo conservador, o deputado Inocêncio de Oliveira (1938-...), pernambucano de Serra Talhada e proprietário da Casa de Saúde e Maternidade São Vicente, conveniada ao SUS depois presidente do FPL e do Congresso Nacional, que ilustra os vínculos existentes entre a prestação de serviços privados ao SUS e o mundo político.

Em 1979, aos 37 anos, Hesio já era um dos mais destacados críticos do sistema de saúde brasileiro, tendo sido um dos criadores do Instituto de Medicina Social da UERJ, que hoje leva o seu nome, e fora um dos responsáveis pelo importante documento apresentado por Sérgio Arouca. No Simpósio, Hesio foi uma das mais importantes lideranças pela mudança desse sistema, sendo o primeiro debatedor da conferência de abertura proferida pelo médico e deputado da ARENA Roberto Santos ${ }^{1}$ (1926-2021), "A Saúde no contexto do desenvolvimento social e econômico". Os outros debatedores foram Aloysio Fernandes, presidente da Federação Brasileira de Hospitais (FBH), defensor dos interesses do setor privado na saúde, e Carlos Gentile de Mello (1918-1982), um dos principais aliados de Hesio na mudança da saúde brasileira e um expoente do sanitarismo desenvolvimentista, juntamente com Mário Magalhães da Silveira (1905-1986), que fez a última palestra do Simpósio sobre "A Política de Saúde Pública no Brasil nos últimos 50 anos".

Ao debater a palestra de Roberto Santos, Hesio mostrou sua grande capacidade de aproveitar a situação e as falas dos seus interlocutores para utilizá-las em favor de suas ideias, uma característica muito sua, bem conhecida pelos que com ele 
conviveram. Aproveitou a relação entre saúde e desenvolvimento feita por Roberto Santos para fazer uma vigorosa denúncia da utilização da assistência à saúde do INAMPS em benefício dos interesses de lucro das empresas capitalistas, defendendo, ao final, a necessidade de profunda mudança política "no sentido de se lograr, pelo desenvolvimento, uma sociedade igualitária e, portanto, democrática, no seu âmbito econômico e social”. Desde o início de sua fala (BRASIL, 1980, p. 37-39), Hesio fez uma forte crítica ao modelo econômico do regime militar e suas consequências sobre a vida dos trabalhadores, com insegurança no emprego, alta concentração de renda, privatização da educação e da saúde, afirmando que "as políticas sociais desenvolvidas nos últimos 15 anos, de terem um caráter igualitário redistributivo, têm um caráter reconcentrador e, portanto, antidemocrático e antipopular", tendo se transformado "num importante instrumento de promoção da acumulação capitalista”.

Prosseguiu criticando o "Sistema Nacional de Saúde [recém-criado na época], que não define, ou que deixa margem a interpretaçóes, ao acaso, das relaçóes entre setor público e privado" [...] "Cabe indicar que nas relações entre o setor público e o privado leva vantagem é o privado. O público é desprestigiado.”

Aproveitou para espetar o debatedor seguinte, que defenderia o setor privado, denunciando "os maléficos resultados do Plano de Pronta Ação (PPA), principalmente em São Paulo onde cerca de 600.000 atendimentos de emergência ou de pronto atendimento na realidade não eram de emergência, e simplesmente atendiam à lógica da lucratividade do setor privado". Hesio denunciou, ainda, que na época, "a assistência médica e o financiamento da assistência médica significam, antes de tudo, uma forma de contribuição do assalariado ao crescimento da empresa médica privada lucrativa", ligando de forma contundente, que as contribuiçôes previdenciárias dos assalariados se dirigiam, na verdade, "ao crescimento do setor privado lucrativo".

Finalizou, aproveitando para dizer que a intervençáo do deputado Roberto Santos "nos coloca em face de um desafio: no campo das políticas sociais, o que significa, hoje, a democratização? Se entendo que, nestes últimos 15 anos, as políticas sociais não tiveram caráter igualitário e redistributivo, e sim um caráter reconcentrador e desigual, [...] dado que esta política não atende aos interesses populares, nem atende aos do caráter igualitário esperado das políticas sociais, os rumos de uma política de oposição e de uma política alternativa para enfrentar os problemas apontados. Significaria, em outros termos, não exercer a política como a arte do possível, ou a política como a arte da conciliação, a política com arte, no caso da saúde, dessa 
convivência ambígua entre o setor público e o privado; significaria [...] a política como travessia, travessia no sentido de se lograr, pelo desenvolvimento, uma sociedade igualitária e, portanto, democrática, no seu âmbito econômico e social".

A intervenção de Hesio no I Simpósio é um exemplo eloquente da forma com que sempre agiu em defesa de suas ideias. Hesio nunca deixou de defender de forma corajosa suas posiçóes pelo direito à saúde e da necessidade de um sistema público e universal, assim como era um duro crítico dos interesses privados no setor, mas o fazia de forma extremamente hábil. Sempre que podia, partia dos argumentos dos seus interlocutores, mesmo quando estes tinham posiçôes distintas e até opostas às dele - como era o caso de Roberto Santos - aproveitando partes de seus argumentos para recolocar a questão de forma a servir à luta pelo SUS e pelo direito à saúde.

\section{Referência}

BRASIL. Congresso Nacional. Câmara dos Deputados. Comissão de Saúde. I Simpósio sobre Politica Nacional de Saúde, Brasília, 1979. Brasília: Câmara dos Deputados, Centro de Documentação e Informação, 1980, 280p.

\section{Nota}

${ }^{1}$ Médico, professor titular da Faculdade de Medicina da Universidade Federal da Bahia, político da ARENA, depois do extinto Partido Popular, criado por Tancredo Neves depois do fim do bipartidarismo. Foi ex-governador indicado da Bahia (1975 e 1979) e ex-ministro da Saúde do governo de José Sarney, entre 1986 e 1987, tendo aberto também a icônica $8^{\text {a }}$ Conferência Nacional de Saúde. 